\title{
Genetic and Morphological Factors Influence Mummy Berry Blight Resistance in Highbush Blueberry Cultivars
}

\author{
M.K. Ehlenfeldt ${ }^{1}$, A.W. Stretch ${ }^{2}$, and V. Brewster ${ }^{3}$ \\ U.S. Department of Agriculture, Agricultural Research Service, Rutgers \\ Blueberry and Cranberry Research Center, Lake Oswego Road, Chatsworth, \\ NJ 08019
}

Additional index words. Vaccinium corymbosum, Monilinia vaccinii-corymbosi, Vaccinium angustifolium

\begin{abstract}
The resistance of $\mathbf{4 8}$ highbush blueberry cultivars and selections to the blight phase of mummy berry disease, incited by the fungus Monilinia vaccinii-corymbosi (Reade) Honey, was examined in relation to percent Vaccinium angustifolium Ait. ancestry, season of fruit maturity, and shoot growth during the primary infection phase. Correlations of percent blighting with percent $V$. angustifolium ancestry were significant across 3 years, but correlations with fruit maturity were significant in only 2 of 3 years. Correlations of percent blighting with early shoot growth were significant in both years measured, with $r$ values of 0.54 in 1994, 0.83 in 1995, and 0.83 across years. A multiple regression found only shoot growth highly significant for susceptibility and rendered $V$. angustifolium ancestry and season of fruit maturity nonsignificant. Resistant cultivars exhibiting early shoot elongation suggest that resistance can be either biochemically or escape based.
\end{abstract}

Mummy berry is the most important widespread fungal disease of blueberry in North America (Eck, 1988). The fungus overwinters on the soil surface as a pseudosclerotium (mummy) that produces apothecia in early spring. Ascospores produced by the apothecia are capable of inducing blight on newly emerging leaf, stem, and flowerbud growth (Batra, 1983). The conidia subsequently produced on blighted tissue are carried by bees or wind to stigmas where they germinate, grow down the style into the ovary, and eventually produce a mummified fruit to complete the life cycle.

Mummy-berry-resistant highbush blueberry cultivars offer an alternative to chemical control, which depends on two fungicides, N,N'-[1,4-piperazinediylbis(2,2,2-trichloroethylidene)]bisformamide (triforine) and methyl 1-(butylcarbamoyl)-2-benzimideazolecarbamate (benomyl). Resistant cultivars could complement proven cultural control practices, making it possible to eliminate or reduce fungicide use. Several studies have demonstrated that various levels of resistance to $M$. vacciniicorymbosi are present in highbush blueberry cultivars (Nelson and Bittenbender, 1971; Pepin and Toms, 1969; Varney and Stretch, 1966). In a previous study (Stretch et al., 1995), we reported the blighting resistance of 52 Vaccinium corymbosum L. (highbush) blue-

Received for publication 6 Apr. 1995. Accepted for publication 13 Dec. 1995. The cost of publishing this paper was defrayed in part by the payment of page charges. Under postal regulations, this paper therefore must be hereby marked advertisement solely to indicate this fact.

${ }^{1}$ Research Geneticist.

${ }^{2}$ Research Plant Pathologist.

${ }^{3}$ Plant Pathologist. berry cultivars. Preliminary observations of blight susceptibility suggested that cultivar susceptibility might be related to any of the following factors: the relative proportion of $V$. angustifolium (lowbush blueberry) ancestry of a cultivar, its shoot length, its total number of shoots, and earliness of ripening relative to other cultivars. In this study, our objective was to determine the relationship of these factors to blight susceptibility.

\section{Materials and Methods}

A group of 52 cultivars and selections assembled as a screening population for blight resistance and the methodology used to evaluate them have been described previously (Stretch et al., 1995). A subset of 48 cultivars and selections (with the addition of 'Nelson' and 'Legacy') for which complete data on genetic composition and season of maturity could be reliably determined were used in this study (see Table 1). The percent shoot blight data in 1993 and 1994 were taken from Stretch et al. (1995) and was supplemented with measurements in 1995 from further evaluations. Blighted shoots were evaluated between 26 Apr. and 14 May 1993, 12 Apr. and 19 May 1994, and 20 Apr. and 18 May 1995.

In 1994 and 1995, vegetative shoot development was measured for all cultivars and selections in the blighting evaluation. Plants were evaluated in two replications (one plant per replication) at opposite ends of the experimental plot by measuring five shoots per plant and calculating an average value. In 1994, initial measurements focused on measuring the longest shoots; however, by 20 Apr., emphasis shifted to determining a value that represented the average shoot growth of the plant. Plants were evaluated three times a week be- tween 11 Apr. and 2 June 1994 and 10 and 21 Apr. 1995, representing the period from initial vegetative budbreak through the period of $M$. vaccinii-corymbosiapothecial viability in both years and the entire season of blight occurrence in 1994.

Percentage of $V$. angustifolium germplasm for cultivars and selections was determined using tables from Hancock and Siefker (1982) and Ehlenfeldt (1994). Information on season of fruit ripening was adapted from information by Hancock et al. (1986) and was supplemented, as necessary, by information from release notices and other sources.

Statistical analyses were performed using MSTAT-C statistical analysis software (Michigan State Univ., East Lansing). Analysis of cultivar shoot length used means of shoot length across the first full week of the experiment, the period during which apothecia were most prevalent. Average shoot lengths for cultivar groups in Fig. 1 were calculated using the Tukey-Kramer method for calculating minimum significant distance (Sokal and Rohlf, 1981).

\section{Results and Discussion}

Each of the three years exhibited different degrees of blighting, with ranges of $1 \%$ to $78 \%, 0 \%$ to $43 \%$, and $7 \%$ to $92 \%$ in 1993 , 1994, and 1995, respectively (Table 1).

An initial concern was to determine whether cultivars or selections with many shoots were more likely to become infected simply because more foliage was present as target tissue. This question was examined through correlations of shoot blight percentage vs. total shoot count. This correlation was significant in $1994(r=0.30, P=0.045)$ but not in $1993(r$ $=0.04, P=1.000)$ or $1995(r=0.14, P=0.303)$. The significance in 1994 may reflect that infection was lower and cultivars with more shoots intercepted more inoculum. Because of this difference between years, subsequent analyses dealt separately with 1993, 1994, 1995, and 3-year-average infection ratings.

Percent $V$. angustifolium ancestry was examined as a factor in susceptibility because several of the most severely infected cultivars were known to contain significant percentages of $V$. angustifolium germplasm (Table 1). Correlation of blight incidence with percent $V$. angustifolium germplasm was highly significant $(P<0.001)$ for 1994,1995 , and the 3 -year average but had marginal significance in 1993 $(P=0.042)$ (Table 2). The lesser significance in 1993 suggests that germplasm composition at the species level may be a factor in blight susceptibility but may not be a reliable indicator. Indeed, some cultivars, such as 'Rancocas' and 'Bluetta', that have one-quarter or more $V$. angustifolium germplasm are relatively resistant to blighting.

Season of ripening generally would not be considered a factor correlated with shoot blighting because fruit maturity would seem to be largely independent of shoot growth. Pepin and Toms (1969), however, noted that blightresistant cultivars were generally late ripening, although late ripening itself did not guar- 
antee resistance. Our studies were in general agreement with their study: early ripening cultivars appeared to be generally more susceptible to blighting than later-maturing cultivars (Table 1). Correlation of blight incidence with season of ripening was significant for the 3 -year average $(r=-0.52, P<0.001), 1994(r$ $=-0.37, P=0.011)$, and $1995(r=-0.54, P<$ $0.001)$ but not for $1993(r=-0.26, P=0.076)$ (Table 2). Part of the relationship may be due to the fact that season of ripening and $V$. angustifolium composition are strongly correlated $(r=-0.45, P<0.001)$.

Because we suspected that some cultivars, such as 'Bluejay', may derive a measure of resistance to blighting via escape, shoot length during the infection phase was examined. Pepin and Toms (1969) found "no consistent relationship between...opening of buds... and disease rating." Our data exhibited a highly significant correlation between blight incidence and the first-week average shoot length for $1994(r=0.54, P<0.001), 1995(r=0.83, P<$ $0.001)$, and combined years $(r=0.83, P<$ 0.001) (Table 1).

A multiple regression, incorporating percent $V$. angustifolium ancestry, season of ripening, and average early shoot growth (length) across 1994 and 1995 against the average percent blight in corresponding years, produced a multiple regression coefficient of $r=$ 0.85 . The standard partial regression coefficients for $V$. angustifolium composition ( $r=$ $0.19, P=0.054)$, season of ripening $(r=-0.01$, $P=0.450)$, and early shoot growth $(r=0.70$, $P<0.001)$ indicated that shoot length is the most significant single factor and that the significant individual factor correlations with blight incidence (Table 2) are due to their relationship to shoot length.

A comparison of shoot length data for the most resistant cultivars, the most susceptible cultivars, and the cultivars overall revealed that shoots of the most susceptible cultivars were $32 \%$ longer than the overall values for cultivars and selections during the first week in 1994 and 91\% longer in 1995 (Fig. 1). In contrast, the most resistant cultivars exhibited $18 \%$ less shoot development than the cultivars overall during the first week in 1994 and $42 \%$ less in 1995. These differences suggest that, in some cases, resistance may be partially due to escape and that a threshold shoot length range exists that may limit susceptibility. Analysis of shoot length data shows statistical differences between cultivars (Table 1) but is best characterized as exhibiting broad overlap. Relatively resistant cultivars, such as 'Bluetta', 'Elizabeth', 'Darrow', 'Pioneer', and 'Duke', show no statistical differences from several susceptible cultivars with longer shoots, such as 'Bluegold', 'Northsky', and 'Croatan'. However, 'Bluejay', the most resistant cultivar, shows the least shoot growth (along with 'Elliott') and, thus, may derive some or all of its resistance from escape. This finding implies that there are two aspects to resistance, a morphological component and a biochemical component. If this assumption is correct, cultivars with true biochemical resistance would express resistance regardless of shoot length,
Table 1. Ranking of highbush blueberry cultivars for blight susceptibility, percent Vaccinium angustifolium ancestry, season of ripening, and shoot length.

\begin{tabular}{|c|c|c|c|c|}
\hline $\begin{array}{l}\text { Cultivar } \\
\text { or selection }\end{array}$ & $\begin{array}{c}\text { 3-Year } \\
\text { mean blight } \\
\text { rating }(\%)\end{array}$ & $\begin{array}{l}\text { V. angustifolium } \\
\text { ancestry (\%) }\end{array}$ & $\begin{array}{c}\text { Season } \\
\text { of ripening }^{\mathrm{z}}\end{array}$ & $\begin{array}{c}2-\text { Year } \\
\text { mean shoot } \\
\text { length }(\mathrm{mm})^{y}\end{array}$ \\
\hline Northblue & 64.8 & 26.6 & 1 & $10.3 \mathrm{a}-\mathrm{c}$ \\
\hline Bluehaven & 63.9 & 25.0 & 3 & $12.2 \mathrm{a}$ \\
\hline Bluegold & 60.5 & 14.1 & 5 & $8.6 \mathrm{a}-\mathrm{g}$ \\
\hline Northsky & 49.7 & 26.6 & 1 & $8.6 \mathrm{a}-\mathrm{h}$ \\
\hline Croatan & 46.6 & 6.3 & 1 & $8.6 \mathrm{a}-\mathrm{h}$ \\
\hline Harrison & 46.1 & 6.3 & 2 & $9.4 \mathrm{a}-\mathrm{e}$ \\
\hline Morrow & 43.6 & 3.1 & 1 & $8.0 \mathrm{~b}-\mathrm{i}$ \\
\hline Sierra & 42.7 & 2.4 & 3 & $6.9 c-1$ \\
\hline Patriot & 40.5 & 28.1 & 3 & $11.6 \mathrm{a}-\mathrm{b}$ \\
\hline Murphy & 39.4 & 6.3 & 2 & $10.0 \mathrm{a}-\mathrm{d}$ \\
\hline Blueray & 35.6 & 6.3 & 4 & $3.71-\mathrm{n}$ \\
\hline Coville & 34.8 & 0 & 5 & $3.8 \mathrm{k}-\mathrm{n}$ \\
\hline Spartan & 33.4 & 6.3 & 2 & $4.9 \mathrm{~h}-\mathrm{n}$ \\
\hline Bluechip & 32.1 & 6.3 & 3 & $9.3 \mathrm{a}-\mathrm{e}$ \\
\hline June & 29.2 & 25.0 & 2 & $3.41-n$ \\
\hline Bluecrop & 28.2 & 6.3 & 4 & $4.9 \mathrm{~g}-\mathrm{n}$ \\
\hline Northland & 27.9 & 25.0 & 3 & $7.5 \mathrm{c}-\mathrm{k}$ \\
\hline Legacy & $27.5^{\mathrm{x}}$ & 1.6 & 5 & $6.1 \mathrm{e}-\mathrm{n}$ \\
\hline Weymouth & 27.1 & 12.5 & 1 & $7.8 c-j$ \\
\hline Berkeley & 25.7 & 0 & 4 & $4.2 \mathrm{j}-\mathrm{n}$ \\
\hline Angola & 25.5 & 6.3 & 1 & $8.3 \mathrm{~b}-\mathrm{i}$ \\
\hline Wareham & 24.0 & 0 & 5 & $4.1 \mathrm{j}-\mathrm{n}$ \\
\hline Cabot & 23.5 & 0 & 3 & $8.9 \mathrm{a}-\mathrm{f}$ \\
\hline Herbert & 21.6 & 0 & 4 & $3.51-\mathrm{n}$ \\
\hline Sunrise & 20.0 & 17.2 & 2 & $5.4 \mathrm{f}-\mathrm{n}$ \\
\hline Atlantic & 19.4 & 0 & 5 & $3.1 \mathrm{~m}-\mathrm{n}$ \\
\hline Rancocas & 19.2 & 25.0 & 4 & $4.6 \mathrm{i}-\mathrm{n}$ \\
\hline Earliblue & 18.3 & 6.3 & 1 & $4.2 \mathrm{j}-\mathrm{n}$ \\
\hline Nelson & $18.1^{\mathrm{x}}$ & 3.1 & 5 & $5.8 \mathrm{e}-\mathrm{n}$ \\
\hline Dixi & 16.7 & 0 & 5 & $4.3 \mathrm{j}-\mathrm{n}$ \\
\hline Meader & 16.6 & 6.3 & 4 & $5.3 \mathrm{f}-\mathrm{n}$ \\
\hline Ivanhoe & 15.1 & 6.3 & 5 & $4.6 \mathrm{i}-\mathrm{n}$ \\
\hline Pioneer & 14.9 & 0 & 4 & $6.5 \mathrm{~d}-\mathrm{m}$ \\
\hline Lateblue & 14.4 & 0 & 7 & $3.9 \mathrm{k}-\mathrm{n}$ \\
\hline Bluetta & 13.8 & 28.1 & 1 & $5.5 \mathrm{f}-\mathrm{n}$ \\
\hline Toro & 13.4 & 6.3 & 4 & $3.61-n$ \\
\hline Burlington & 12.2 & 0 & 6 & $4.1 \mathrm{j}-\mathrm{n}$ \\
\hline Elizabeth & 12.1 & 0 & 6 & $5.5 \mathrm{f}-\mathrm{n}$ \\
\hline 11-104 & 9.6 & 0 & 4 & $3.51-\mathrm{n}$ \\
\hline Rubel & 9.1 & 0 & 4 & $3.31-\mathrm{n}$ \\
\hline Katherine & 8.1 & 0 & 4 & $3.61-n$ \\
\hline Jersey & 7.8 & 0 & 5 & $2.5 \mathrm{n}$ \\
\hline Pemberton & 7.0 & 0 & 4 & $3.1 \mathrm{~m}-\mathrm{n}$ \\
\hline Darrow & 5.9 & 3.1 & 6 & $5.3 \mathrm{f}-\mathrm{n}$ \\
\hline Stanley & 5.9 & 0 & 5 & $3.41-n$ \\
\hline Duke & 4.5 & 3.9 & 2 & $7.7 c-j$ \\
\hline Elliott & 3.6 & 0 & 7 & $2.9 \mathrm{~m}-\mathrm{n}$ \\
\hline Bluejay & 2.5 & 0 & 3 & $2.9 \mathrm{~m}-\mathrm{n}$ \\
\hline
\end{tabular}

${ }^{\mathrm{z}} 1=$ very early, $2=$ early, $3=$ early midseason, $4=$ midseason, $5=$ late midseason, $6=$ late, and $7=$ very late 'Mean of values from first week of evaluation. Mean separation by least significant difference test at $P=0.05$. ${ }^{x}$ Values represent 2 years of data only. These cultivars were not included in statistical analyses that used 3 years of data.

Table 2. Correlation coefficients among Monilinia vaccini-corymbosii blight incidence, percent Vaccinium angustifolium ancestry, season of ripening, and shoot length.

\begin{tabular}{|c|c|c|c|c|c|c|}
\hline \multirow[b]{2}{*}{ Variable } & \multirow{2}{*}{$\begin{array}{l}\text { Season of } \\
\text { ripening }^{2}\end{array}$} & \multirow{2}{*}{$\begin{array}{c}\text { 2-Year shoot } \\
\text { length }^{y}\end{array}$} & \multicolumn{4}{|c|}{ Blight incidence (\%) } \\
\hline & & & 1993 & 1994 & 1995 & 3-Year avg \\
\hline $\begin{array}{c}\text { V. angustifolium } \\
\text { ancestry }(\%)\end{array}$ & $-0.45^{* * *}$ & $0.52^{2 * *}$ & $0.30^{*}$ & $0.56^{* * * *}$ & $0.53^{* * *}$ & $0.57^{* * *}$ \\
\hline Season of ripening & & $-0.52^{* * *}$ & -0.26 & $-0.37^{*}$ & $-0.54^{* * * *}$ & $-0.52^{* * *}$ \\
\hline Shoot length 1994 & & & & $0.54^{* * *}$ & --- & --- \\
\hline Shoot length 1995 & & & & & $0.83^{* * * *}$ & --- \\
\hline
\end{tabular}

(2-year average)

$0.83^{* * *}, x$

${ }^{2}$ Ripening values based on numerical rating from 1 to 7 , with $1=$ very early and $7=$ very late.

${ }^{\mathrm{y}}$ Correlations based on mean values from first week of evaluation.

${ }^{x}$ Correlation based on blighting data from 1994 and 1995 only.

**** Significant at $P<0.05$ or 0.001 , respectively. 


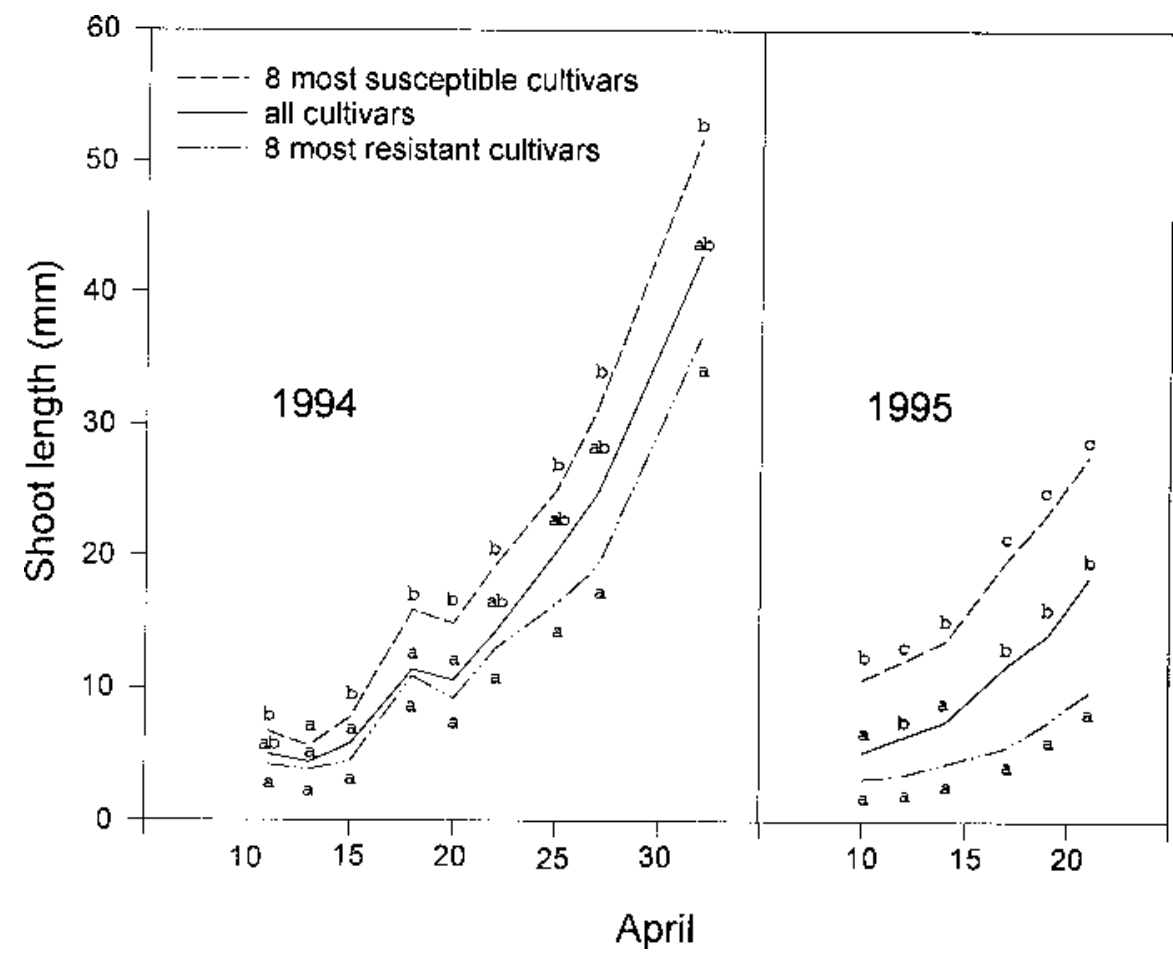

Fig. 1. Average shoot length of highbush blueberry cultivars during the 1994 and 1995 infection periods. Each cultivar had five measurements per plant in two replications. Means were tested for each date at $P \leq 0.05$ using a Tukey-Kramer procedure for calculating minimum significant difference at a given date.

whereas cultivars with lesser biochemical resistance may become infected to a greater or lesser degree depending on shoot length. Very susceptible types would have no biochemical resistance and consistently early vegetative shoot growth. 'Duke', a recently released and widely planted cultivar, has shoot growth similar to some of the most susceptible cultivars, yet is among the most blight resistant. This study suggests that although some of the resistance identified may be due to escape, some is true resistance usable in breeding.

\section{Literature Cited}

Batra, L.R. 1983. Monilinia vaccinii-corymbosi (Sclerotiniaceae): Its biology on blueberry and comparison with related species. Mycologia 75:131-152.

Eck, P. 1988. Blueberry science. Rutgers Univ. Press, New Brunswick, N.J.

Ehlenfeldt, M.K. 1994. The genetic composition and tetrasomic inbreeding coefficients of highbush blueberry cultivars. HortScience 29:321324.

Hancock, J.F. and J.H. Siefker. 1982. Levels of inbreeding in highbush blueberry cultivars. HortScience 17:363-366.

Hancock, J.F., J.H. Siefker, and J. Nelson. 1986. Highbush blueberry varieties for Michigan. Michigan State Univ. Ext. Bul. E-1456.

Nelson, J. and H.C. Bittenbender. 1971. Mummy berry disease occurrence in a blueberry selection test planting. Plant Dis. Rptr. 55:651-653.

Pepin, H.S. and H.N.W. Toms. 1969. Susceptibility of highbush blueberry varieties to Monilinia vaccinii-corymbosi. Phytopathology 59:18761878.

Sokal, R.R. and F.J. Rohlf. 1981. Biometry. 2nd ed. W.H. Freeman and Co., New York.

Stretch, A.W., M.K. Ehlenfeldt, and V. Brewster. 1995. Mummy berry blight resistance in highbush blueberry cultivars. HortScience 30:589591.

Varney, E.H. and A.W. Stretch. 1966. Diseases and their control, p. 236-279. In: P. Eck and N.F. Childers (eds.). Blueberry culture. Rutgers Univ. Press, New Brunswick, N.J. 